\title{
April 1965
}

This paper was submitted for publication in the open literature at least 8 months prior to the issuance date of this Microcard. Since the U.S.A.E.C. has no evidence that it has been published, the paper is being distributed in Microcard form as a preprint.

\section{E-232 \\ EFFECTS OF SURFACE PREPARATIONS ON BOND STRENGTH OF MAGNESIUM}

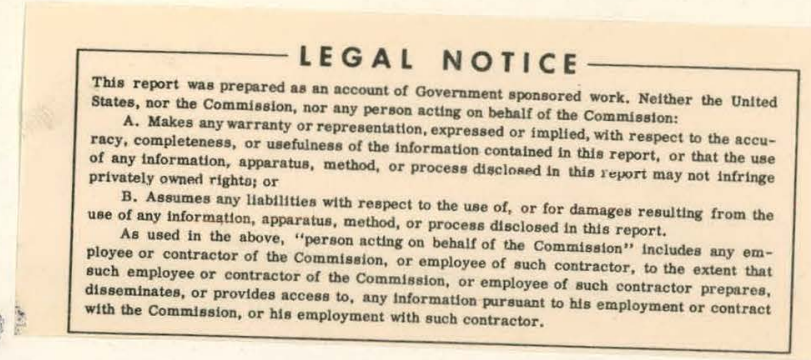

PREPARED BY:

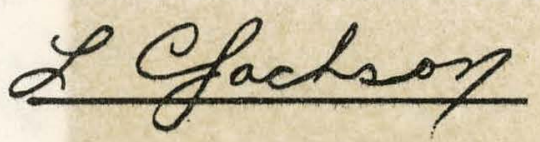

LLOYD C. JACKSON

MATER IALS FNG INEER ING
APPROVED BY:

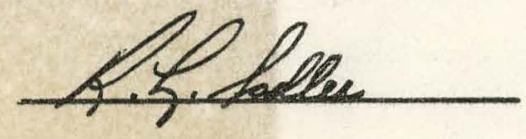

R. L. SADLER

SECTIUN SUPERVISOR ORGANIZATION 832-I

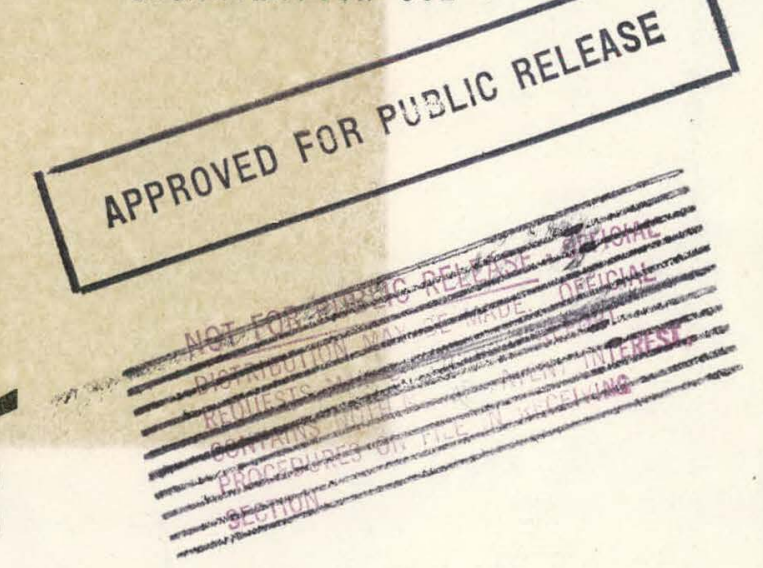




\section{DISCLAIMER}

This report was prepared as an account of work sponsored by an agency of the United States Government. Neither the United States Government nor any agency Thereof, nor any of their employees, makes any warranty, express or implied, or assumes any legal liability or responsibility for the accuracy, completeness, or usefulness of any information, apparatus, product, or process disclosed, or represents that its use would not infringe privately owned rights. Reference herein to any specific commercial product, process, or service by trade name, trademark, manufacturer, or otherwise does not necessarily constitute or imply its endorsement, recommendation, or favoring by the United States Government or any agency thereof. The views and opinions of authors expressed herein do not necessarily state or reflect those of the United States Government or any agency thereof. 


\section{DISCLAIMER}

Portions of this document may be illegible in electronic image products. Images are produced from the best available original document. 


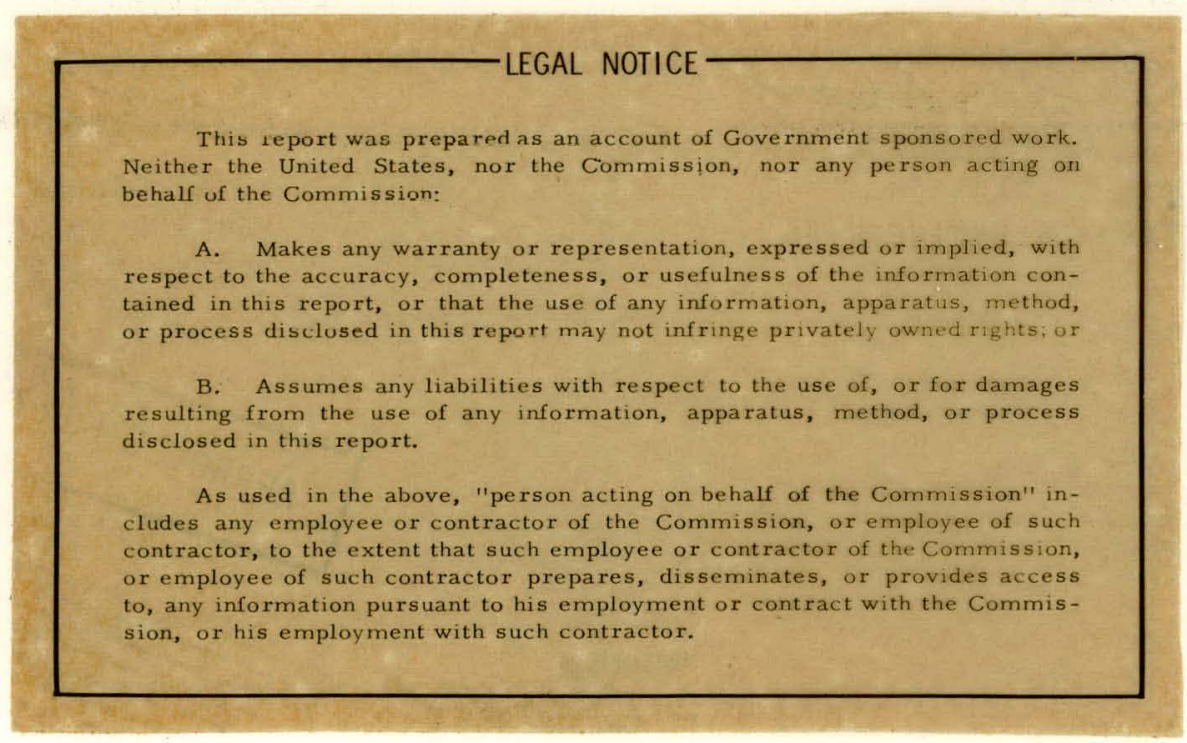


ACKNOWLEDGEMENT • . . . . . . . . . . IV

ABSTRACT. . . . . . . . . . . . . .

I. INTRODUCTION . . . . . . . . . . . . . . 1

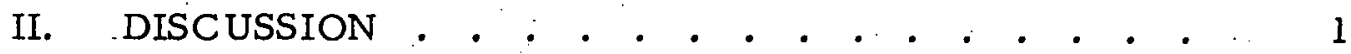

A. Magnesium Alloy Composition. . . . . . . 1

B. Adhesive Characterization . . . . . . 2

C. Testing and Fabrication Conditions . . . . 3

D. Surface Preparations . . . . . . . . 3

1. Observations . . . . . . . . . 3

2. Blackening (Ebonol) Process. . . . . 4

3. Comparison of Surface Preparations. . . 5

4. Low and Elevated Temperature

Adhesive Strength Comparisons . . . . 8

5. Cure Temperature Effects on Bond Strength . . . . . . . . . 8

6. Time and Temperature Effects. . . . 12

E. Processing . . . . . . . . . . . . . 12

1. Contamination Effects . . . . . . . 12

2. Solution Controls . . . . . . . . 13

3. Packaging. . . . . . . . . . . . 13 


\section{TABLES}

PAGE

I. Nominal Composition of Principal Alloying Elements of Magnesium Alloys . . . . . . . . . . .

II. Surface Preparation Selection, In Order of Best Bond Strength Per Adhesive Classification. . .

III. Typical Shear Strength on Aluminum at Room Temperature.

IV. Effects of Cure Temperature on Shear Strength of Bonded Magnesium Alloys . . . . . . .

\section{APPENDICES}

I. Procedures Used for Preparing Magnesium Surfaces for Adhesive Bonding . . . . . . . 14

II. References . . . . . . . . . . . . 16 


\section{ILLUSTRATIONS}

FIGURE

PAGE

I Comparison of Shear Strengths of Four Epoxy

Adhesives with Six Surface Preparations and

Six Magnesium Alloys . . . . . . . . . 6

2 Comparison of Shear Strength of AZ31-H24

Magnesium Bonded with Four Epoxy Adhesives

(Hot Chromic Acid Etch Surface Preparation)

3 Comparison of Shear Strength of ZK60-T6

Magnesium Bonded with Four Epoxy Adhesives

(Hot Chromic Acid Etch Surface Preparation).

Cured Four Hours at 165 Degrees F.

4 Comparison of Shear Strength of HM21-T8

Magnesium Bonded with Four Epoxy Adhesives

(Hot Chromic Acid Etch Surface Preparation).

Cured Four Hours at 165 Degrees F.

5 Comparison of Shear Strength of HK31-H24

Magnesium Bonded with Four Epoxy Adhesives

(Hot Chromic Acid Etch Surface Preparation).

Cured Four Hours at 165 Degrees F. . . . . . . 10

6 Comparison of Shear Strength of LAl41-0

Magnesium Bonded with Four Epoxy Adhesives (Hot Chromic Acid Etch Surface Preparation).

Cured Fonr Hours at 165 Degrcco $F$ 


\section{ACKNOWLEDGEMENT}

Appreciation is expressed to $\mathrm{Mr}$. Steve Allen for his many observations and for his performance of the work on surface preparation and adhesive bonding of the magnesium alloys. 


\section{ABSTRACT}

In order to obtain optimum bond strengths with magnesium alloys, equal consideration must be given to the specific alloy, to the method of surface preparation, and to the adhesive.

Dimensional tolerances directly influence the selection of a surface preparation to be used on magnesium alloys prior to adhesive bonding. Certain chemical etches are unsatisfactory because they remove too much magnesium. Other surface preparations may cause smut formation to develop to a point that these loose particles may interfere with optimum bond strength.

A problem with epoxy adhesives is that the chemical nature of the epoxy formulation appears to have a sensitivity to the surface chemistry condition of a magnesium alloy after a surface preparation has been used on the alloy.

Test data recorded in this report compare shear strengths of six alloys after application of six surface preparations (including a new process using "Ebonol"), and bonding with four types of epoxy adhesives. 


\section{INTRODUCTION}

Available literature on the adhesive bonding of magnesium deals only with the AZ 31 alloy. As more uses for magnesium are found, and more alloys are developed, the subject of surface preparation becomes more important. It cannot be assumed that all magnesium alloys respond in the same manner to a particular chemical etch, nor can it be assumed that various surface preparations for the different magnesium alloys will provide comparable bond capability.

Corrosion may be a problem when using alloys in certain environments. Corrosion could also be caused by an adhesive during or after the curing period. Protection of the magnesium alloy surface from corrosion requires certain chemical treatments prior to the bonding operation.

This paper deals primarily with research into surface preparations for several of the magnesium alloys. Included are discussions of (1) a new surface preparation for magnesium alloys, (2) processing problems which might be encountered, and (3) controls necessary in the use of chemical etches. Data are presented on comparative shear strength of six magnesium alloys, evaluating the effects of six surface preparations and four types of epoxy adhesives of low and high modulus.

It is expected that modifications in epoxy adhesive formulation would modify some of the data given in this report.

\section{DISCUSSION}

\section{A. MAGNESIUM ALLOY COMPOSITION}

Magnesium is the lightest metal available today for structures. Selection of a magnesium alloy will, of course, depend upon the properties required by the design or end use. The alloys evaluated in this work can be characterized as follows:

\section{ALLOY}

AZ 31. . . Usable up to temperatures of $200^{\circ} \mathrm{F}$.

HK 31 and HM 21. Suitable up to $600^{\circ} \mathrm{F}$. and $650^{\circ} \mathrm{F}$, respectively. HM 21 has strength superior to that of $\mathrm{HK} 31$.

ZK 60 . . . . High s.trength, rigid alloy, usable up to $300^{\circ} \mathrm{F}$.

LA 141 . . . . Used for low temperature, low stress requirements. Specific gravity is 1.35 compared to 1.8 of other magnesium alloys. 
In order to obtain some of these desired properties, the alloy composition and, of course, the process of manufacture, are varied. It is believed that the minor constituents, whether in elemental metal form, combinations, oxides, etc., cause problems in adhesive bonding areas. The loose, black particles that are formed in varying degrees by the different surface preparations tend to contribute to lower bond strength, or to greater variation in strength values.

The nominal composition of some of the principal alloying elements is given in Table I for each of the magnesium alloys studied. The conditioning of the alloys, as indicated by H24, T5, and 0 , for example, can be expected to influence the dispersion of the minor constituent throughout the magnesium. The conditioning will also affect the chemical nature of the minor constituent.

\section{TABLE I}

Nominal Composition of Principal Alloying Elements of Magnesium Alloys 4

\begin{tabular}{|c|c|c|c|c|c|c|}
\hline Composition & $\begin{array}{c}\mathrm{AZ} 31 \mathrm{~B}- \\
\mathrm{H} 24\end{array}$ & $\begin{array}{c}\mathrm{ZK} 60 \mathrm{~A}- \\
\mathrm{T} 5\end{array}$ & $\begin{array}{c}\mathrm{ZK} 60 \mathrm{~A}- \\
\mathrm{T} 6\end{array}$ & $\begin{array}{c}\text { HM } 21 \mathrm{~A}- \\
\text { T8 }\end{array}$ & $\begin{array}{l}\text { HK } 31 \mathrm{~A}- \\
\mathrm{H} 24\end{array}$ & $\begin{array}{c}\text { LA } 141 \mathrm{~A}-5 \\
0\end{array}$ \\
\hline Aluminum & 3.0 & -- & -- & -- & --- & 1.25 \\
\hline Manganese & --- & --- & -- & 0.5 & $\ldots$ & --- \\
\hline Zinc & 1.0 & 5.5 & 5.5 & -- & $\ldots$ & -- \\
\hline Zirconium & --- & 0.5 & 0.5 & -- & 0.7 & -- \\
\hline Thorium & $\ldots$ & --- & -- & 2. 0 & 3.3 & -- \\
\hline Lithium & --- & -- & $\therefore-$ & -- & --- & 14.0 \\
\hline Magnesium & & $D$ & $\mathrm{~L}$ & $\bar{N}$ & $\bar{E}$ & \\
\hline
\end{tabular}

\section{B. ADHESIVE CHARACTERIZATION}

Four epoxy adhesives were used which could be cured at room temperature or at slightly elevated temperatures. Unless otherwise indicated, the data presented were obtained by curing the four adhesives for four hours at $165^{\circ} \mathrm{F}$. The adhesives were selected to represent a range of modulus, or hardness, that might be found with epoxy adhesives. They are identified as follows:

ADHESIVE

A

B

C

$\mathrm{D}$

\section{TYPE}

Epoxy, rubber-based

Epoxy, polyamide

Epoxy, phenolic

Epoxy, novolac 
Adhesives "A" and " $B$ " are epoxies of the less rigid type which have more impact resistance, some flexibility, and generally are considered usable in the temperature range of $-67^{\circ} \mathrm{F}$ to $165^{\circ} \mathrm{F}$. Adhesives " $C$ " and " $D$ " are of the higher modulus type, brittle, and generally withstand environments ranging from $-67^{\circ} \mathrm{F}$ to $300^{\circ} \mathrm{F}$.

\section{TESTING AND FABRICATION CONDITIONS}

All specimens were tested with a Baldwin Mark G Tensile Tester at a strain rate of 0.05 inch per minute. Jaws of the tensile tester held the specimens two inches from the edge of the overlap. The magnesium specimens were 0.093 inch thick, 4.0 inches long, and 1.0 inch wide. Bonded test specimens were one-half inch overlap. Glue line control was $0.010 \pm 0.002$ inch. Since fillets at the end of the lap joint sometimes affect shear strengths of some adhesives, all fillets were removed. All data given are an average of five test specimens.

\section{SURFACE PREPARATIONS}

\section{Observations}

A characteristic of the various surface preparations studied was the appearance of a black material which might be called "smut". This smut can be rubbed off with a solvent-dampened pad, depending upon the chemical etch used and the magnesium alloy. Such loose, black particles are believed responsible, in some cases, for erratic shear strength results. It is also believed that they contribute to lower bond strengths. Certain magnesium alloys will yield more smut than others for the same surface preparation. Those solutions that tend to react more with magnesium tend to cause more smut formation. The magnesium alloy $\mathrm{ZK}$ 60, for example, will show more smut formation when processed through a $24 / 4$ oz/gal chromium trioxide-sodium nitrate solution than will AZ 31 magnesium. It is also interesting to note that the $\mathrm{T} 6$ condition of $\mathrm{ZK} 60$ will form more smut than the $\mathrm{T} 5$ condition, even though the alloy compositions are essentially equal. The ZK 60 alloy is high in zinc content compared with AZ 31. On the other hand, chromic acid, alone, causes little smut formation to develop with $\mathrm{ZK} 60-\mathrm{T} 6$ or with the AZ 31-H24 alloy. The LA 141 alloy always provided more smut formation than any of the other alloys, regardless of surface preparation.

A phosphoric acid etch solution reacted with the various magnesium alloys in a manner which left a black surface that could be easily wiped off. An acetic acid-sodium nitrate solution removed too much magnesium; an acetic acid solution left a light smut, although it polished only the LA 141 alloy. A sulfuric acid-sodium dichromate solution reacted too violently with the magnesium. Selection of the surface preparations for evaluation on the various magnesium alloys was based, therefore, on the following factors:

a. Development of little or no smut formation.

b. Negligible removal of magnesium by the solution. 
It is expected that othe $r$ surface preparation methods not reported here would provide acceptable bonds and would justify additional investigation.

2. Blackening (Ebonol) Process

An interesting new procedure for depositing a conversion coating on magneșium alloys should be discussed before a comparison is made of the various surface preparations. This procedure is a patented blackening (Ebonol) method normally used for the direct oxidation of copper to form a black oxide. 1, 2, 3 However, the process works very well with some of the magnesium alloys.

The chemistry of the blackening process is essentially the reaction of an inorganic oxidizing agent with copper, or other metals, in a strongly alkaline solution to form an oxide. It is presumed that with magnesium alloys the reaction involves the minor alloying constituents.

The following description indicates the nature of the coating, or surface condition, formed by using the Ebonol " $\mathrm{C}$ " solution.

APPEARANCE

Tan iridescence

Varied rainbow iridescence

Gray

Black
MAGNESIUM

HM 21 and HK 31

AZ 31 and $\mathrm{ZK} 60-\mathrm{T} 5$

ZK 60-T6

LA 141

Details of the process are given in Appendix I. The ZK 60-T6 alloy was the only magnesium processed through the Ebonol "C" solution that had failure within the coat itself when the load was placed on the adhesive bond. Although the composition of $\mathrm{ZK} 60-\mathrm{T} 5$ and $\mathrm{ZK} \mathrm{60-T6} \mathrm{is} \mathrm{the} \mathrm{same,} \mathrm{a} \mathrm{distinct,} \mathrm{visual} \mathrm{difference} \mathrm{between} \mathrm{the} \mathrm{two} \mathrm{was}$ obtained in the appearance of the coatings. Such differences may be. 7 . result of the additional heat treat given to the $\mathrm{T} 6$ condition.

Based on the variations in appearance of the different alloys after being processed through the Ebonol " $C$ " solution, the nature of the coating might suggest that the coating is governed by the minor constituents and their distribution at the surface of the alloys. Differences in the oxide formed (or combinations of metal oxides) are further suggested by the shear strength variations found with the four different epoxy adhesives. These variations are shown later in this report. In some cases, the Ebonol procedure provided a bond capability superior to other means tested. 


\section{Comparison of Surface Preparations}

The surface preparations that were selected for comparison can be basically identified as follows:
(1) Solvent degrease
(2) Chromic acid (room temperature)
(3) Chromic acid (hot)
(4) Alkaline
(5) Dow 17
(6) Ebonol "C"

Details of the procedures are given in Appendix I. Bar charts, each representing the average of five test specimens, are given in Figure 1. These charts show how each adhesive and each surface preparation performs with each magnesium alloy. The information is presented so that surface preparation comparisons can be made on a horizontal line basis. There are four vertical columns of bar charts, each column representing one of the four adhesives evaluated; within each bar chart set, the six magnesium alloys are given. Surface preparation comparisons can be made vertically; adhesive comparisons can be made horizontally.

For convenience, a summation of the bar chart information is presented in Table II, according to classification by adhesive. Each alloy is listed with the selected surface preparations, which appear in the order of best bond capability.

Although the thick Dow 17 coating might provide increased corrosion resistance, failure within the coating itself generally occurs when the load is placed on the bond. As a result, in this work thin coatings in the range of 0.0001 to 0.0003 inch were deposited on all the magnesium alloys.

In selecting a surface preparation for any one of the magnesium alloys, careful consideration must also be given to selection of the type of epoxy adhesive. Selection of the surface preparation and an adhesive for one alloy will, of course, be governed by the level of performance required of the part and how much protection against corrosion is required.

Selection of surface preparation could be critical. In the case of the Ebonol "C" procedure, the bond strength of AZ 31 magnesium with the epoxy polyamide adhesive was 800 - 1100 pounds per square inch greater than when the other surface preparations were used. Other examples can be found in Figure 1 . 
FIGURE 1.

Comparison of Shear Strengths of Four Epoxy Adhesives with Six Surface Preparations and Six Magnesium Alloys
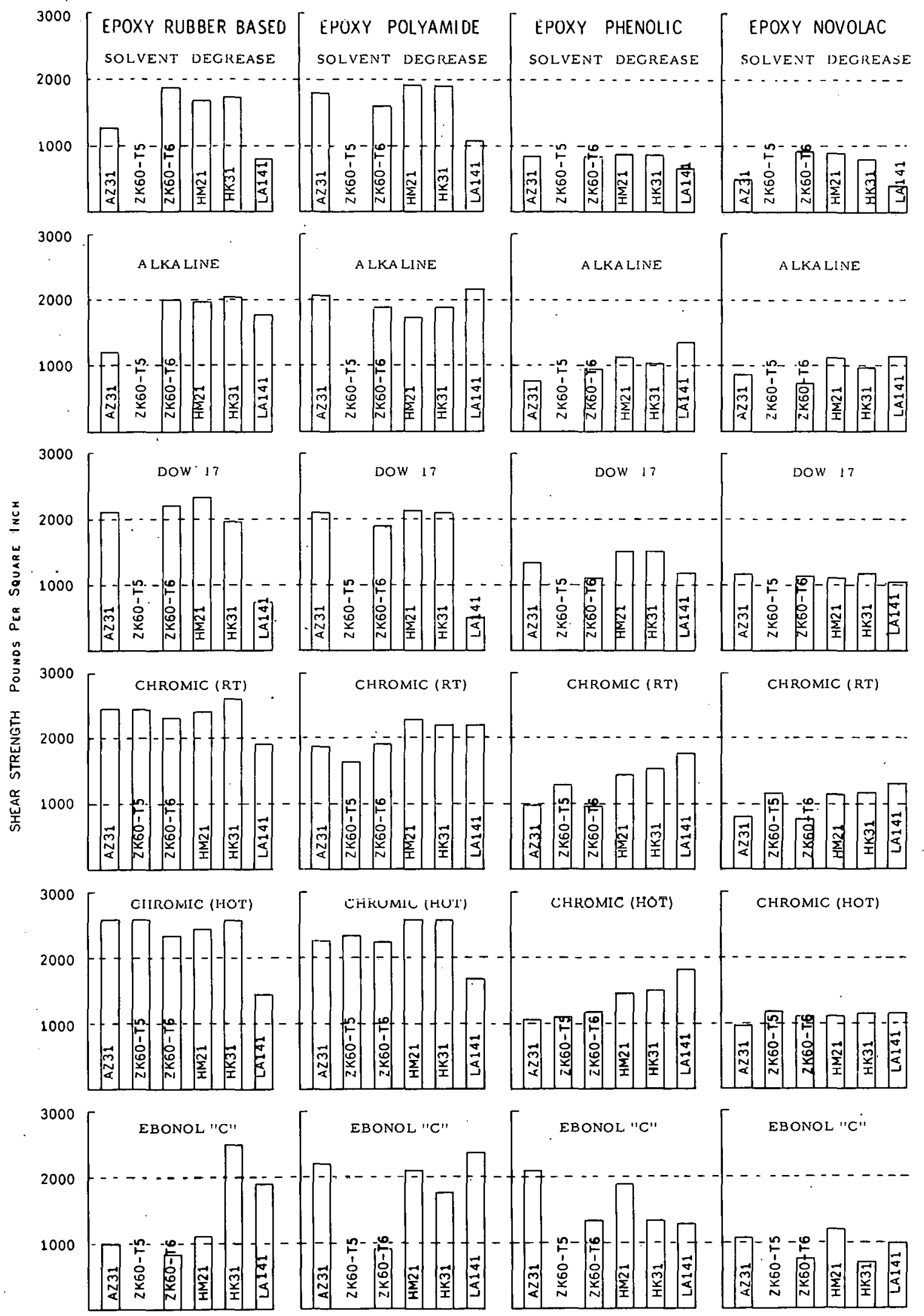


\section{TABLE II}

Surface Preparation Selection, in Order of Best Bond Strength Per Adhesive Classification

\begin{tabular}{|c|c|c|}
\hline & $\begin{array}{l}\text { Adhesive } \\
\text { Evaluated }\end{array}$ & $\begin{array}{l}\text { Surface Preparation Selection in Order of } \\
\text { Greater Bond Capability (PSI in Parentheses) }\end{array}$ \\
\hline \multicolumn{3}{|c|}{ Epoxy, Rubber-Based } \\
\hline \multirow[t]{5}{*}{ With: } & AZ 31 & Hot Chromic (2710); R. T. Chromic (2490); Dow 17 (2120) \\
\hline & $\mathrm{ZK} 60-\mathrm{T} 6$ & Hot Chromic (2330); R. T. Chromic (2280); Dow 17 (2200) \\
\hline & HM 21 & Hot Chromic (2460); R. T. Chromic (2420); Dow 17 (2340) \\
\hline & HK 31 & $\begin{array}{l}\text { Hot Chromic (2658); R. T. Chromic (2500); } \\
\text { Ebonol "C" }(2430) ; \text { Dow } 17(1990)\end{array}$ \\
\hline & LA 141 & Ebonol "C" (1920); R. T. Chromic (1920); Alkaline (1790) \\
\hline \multirow{6}{*}{$\begin{array}{l}\text { Epoxy, } \\
\text { With: }\end{array}$} & Polyamide & \\
\hline & AZ 31 & $\begin{array}{l}\text { Hot Chromic (2210); Ebonol "C" (2150); Dow } 17 \text { (2110); } \\
\text { Alkaline (2040) }\end{array}$ \\
\hline & $\mathrm{ZK} 60-\mathrm{T} 6$ & $\begin{array}{l}\text { Hot Chromic (2170); Alkaline (1890); Dow } 17 \text { (1850); } \\
\text { R. T. Chromic (1830) }\end{array}$ \\
\hline & HM 21 & $\begin{array}{l}\text { Hot Chromic (2718); R. T. Chromic (2280); Dow } 17 \text { (2170); } \\
\text { Ebonol "C" }(2110)\end{array}$ \\
\hline & HK 31 & $\begin{array}{l}\text { Hot Chromic (2700); R T. Chromic (2200); Dow } 17 \text { (2080); } \\
\text { Ebonol "C" (1780) }\end{array}$ \\
\hline & LA 141 & Ebonol "C" (2360); R. T. Chromic (2200); Alkaline (2160) \\
\hline \multicolumn{3}{|c|}{ Epoxy, Phenolic } \\
\hline \multirow[t]{5}{*}{ With: } & AZ 31 & Ebonol "C" (2100) \\
\hline & $\mathrm{ZK} 60-\mathrm{T} 6$ & Ebonol "C" (1310); Hot Chromic (1160); Dow 17 (1120). \\
\hline & HM 21 & $\begin{array}{c}\text { Ebonol "C" (1830); Hot Chromic (1450); Dow } 17 \text { (1430); } \\
\text { R. T. Chromir. (1.47.n) }\end{array}$ \\
\hline & HK 31 & $\begin{array}{l}\text { R. T. Chromic (1510); Hot Chromic (1498); Dow } 17 \text { (1440); } \\
\text { Ebonol "C" }(1320)\end{array}$ \\
\hline & LA 141 & Hot Chromic (1816); R. T. Chromic (1770) \\
\hline Epoxy & Novolac & \\
\hline \multirow[t]{5}{*}{ With: } & AZ 31 & $\begin{array}{c}\text { Dow } 17 \text { (1150); Ebonol "C" (1080); Hot Chromic (970); } \\
\text { R. T. Chromic (810) }\end{array}$ \\
\hline & $\mathrm{ZK} \mathrm{60-T6}$ & Hot Chromic (1140); Dow 17 (1060) \\
\hline & HM 21 & $\begin{array}{c}\text { Ebonol "C" (1210); R. T. Chromic (1140); Hot Chromic } \\
\text { (1092); Alkaline (1080); Dow } 17(1030)\end{array}$ \\
\hline & $\mathrm{HK} 31$ & Dow 17 (1180); R. T. Chromic (1170); Hot Chromic (1120) \\
\hline & LA 141 & $\begin{array}{l}\text { R. T. Chromic (1280); Hot Chromic (1140); Alkaline (1140); } \\
\text { Dow } 17(1010)\end{array}$ \\
\hline
\end{tabular}


If optimum bond capability is to be the design intent, then the re are enough variations to prevent the selection of an "across-the-board" surface preparation. However, in a majority of the tests made, the chromic acid procedure (hot or room temperature) generally offered bond capability equivalent to, or better than, the other methods.

Since much of the data normally developed for adhesives is with aluminum, typical shear strength values of the four epoxy adhesives with aluminum are given in Table III as a point for reference. The following data were obtained with 2024-T3 alclad aluminum (0.063 inch thick) with the adhesives cured four hours at $165^{\circ} \mathrm{F}$.

\section{TABLE III}

Typical Shear Strength on Aluminum at Room Temperature

\begin{tabular}{l|c}
\hline \multicolumn{1}{c|}{ Adhesive } & Pounds per square inch \\
\hline Epoxy, rubber-based & 2900 \\
Epoxy, polyamide & 3400 \\
Epoxy, phenolic & 2700 \\
Epoxy, novolac & 2200
\end{tabular}

4. Low and Elevated Temperature Adhesive Strength Comparisons

The epoxy phenolic and the epoxy novolac adhesives were selected, in part, for their higher temperature $\left(300^{\circ} \mathrm{F}\right)$ strength capability with aluminum, as previously determined. The extent to which these adhesives, as well as the epoxy rubber-based and the epoxy polyamide adhesives, performed with magnesium at temperatures ranging from $-67^{\circ} \mathrm{F}$ to $350^{\circ} \mathrm{F}$ was determined while using the hot chromic acid surface preparation procedure. Cure was four hours at $165^{\circ} \mathrm{F}$. The results of the tests are shown in Figures 2 through 6. Specimens were conditioned $10 \pm 1$ minutes at the temperature of test.

It was found that the lower modulus type adhesives, the epoxy rubber-based, and the epoxy polyamide, generally have higher strength values at room temperatures and at $-67^{\circ} \mathrm{F}$. The epoxy phenolic and the epoxy novolac better withstand $250^{\circ} \mathrm{F}$.

5. Cure Temperature Effects on Bond Strength

Since the four epoxy adhesives have been referred to as room-temperature cured, but all data given have been based on a heat cure, another point for reference appears in order. A comparison of the four adhesives cured four hours at $165^{\circ}$. F versus eight days at room temperature is given in Table IV, using the various magnesium alloys prepared by the hot chromic acid method. 
FIGURE 2.

Comparison of Shear Strength of AZ31-H24 Magnesium Bonded with Four Epoxy Adhesives (Hot Chromic Acid Etch Surface Preparation). Cured Four Hours at 165 Degrees F.

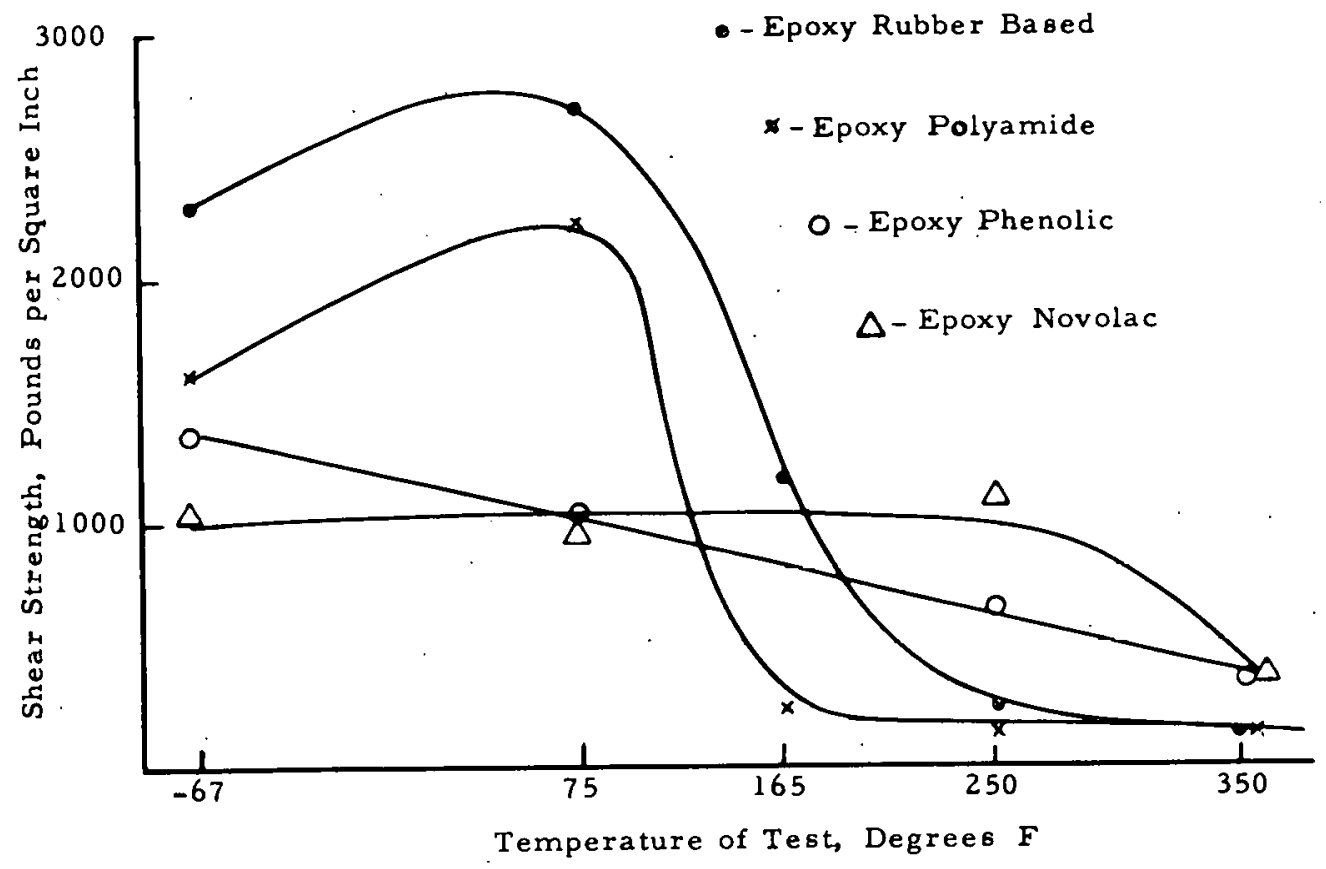

FIGURE 3.

Comparison of Shear Strength of ZK60-T6 Magnesium Bonded with Four Epoxy Adhesives (Hot Chromic Acid Etch Surface Preparation). Cured Four Hours at 165 Degrees F.

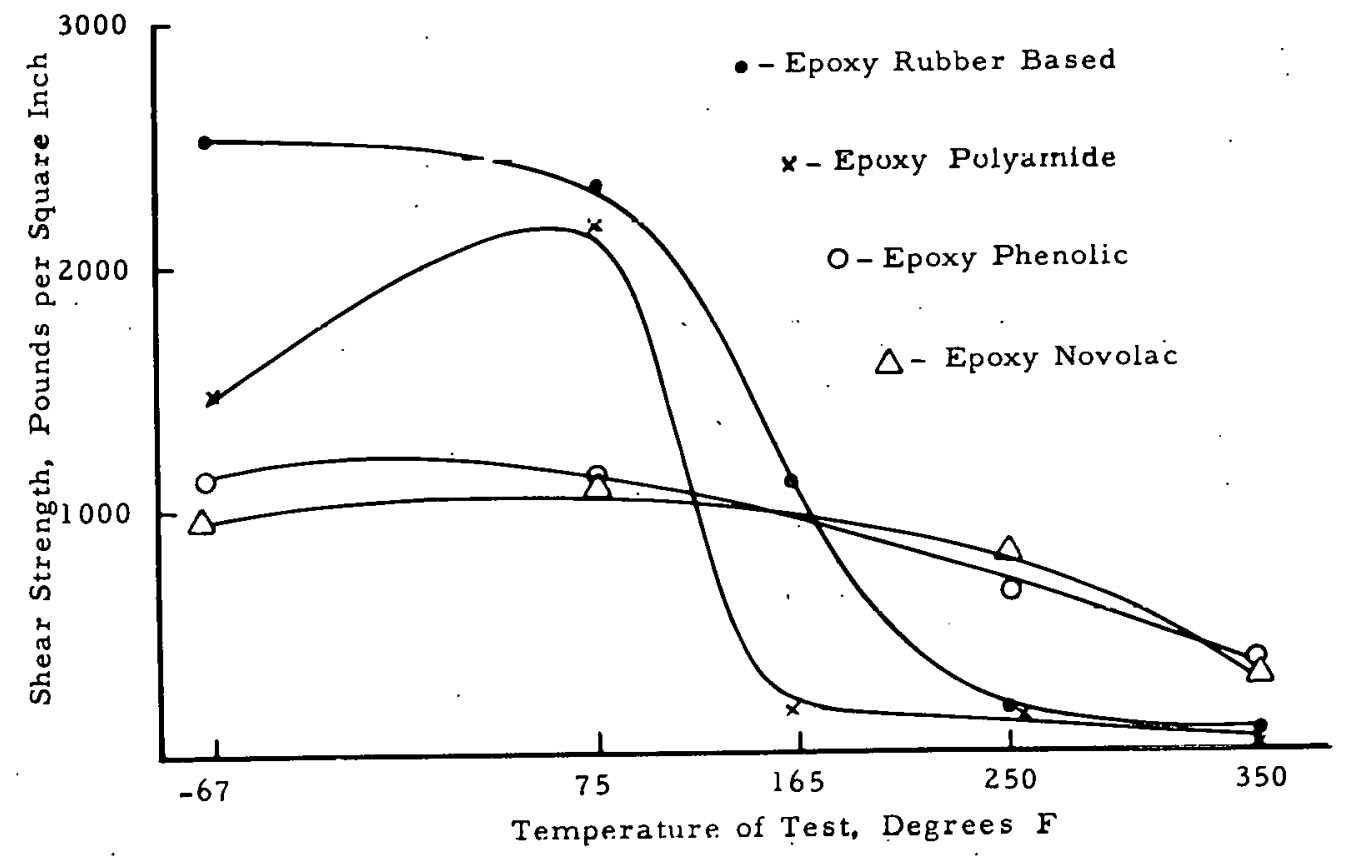


FIGURE 4.

Comparison of Shear Strength of HM2l-T8 Magnesium Bonded with Four Epoxy Adhesives (Hot Chromic Acid Etch Surface Preparation). Cured Four Hours at 165 Degrees F.

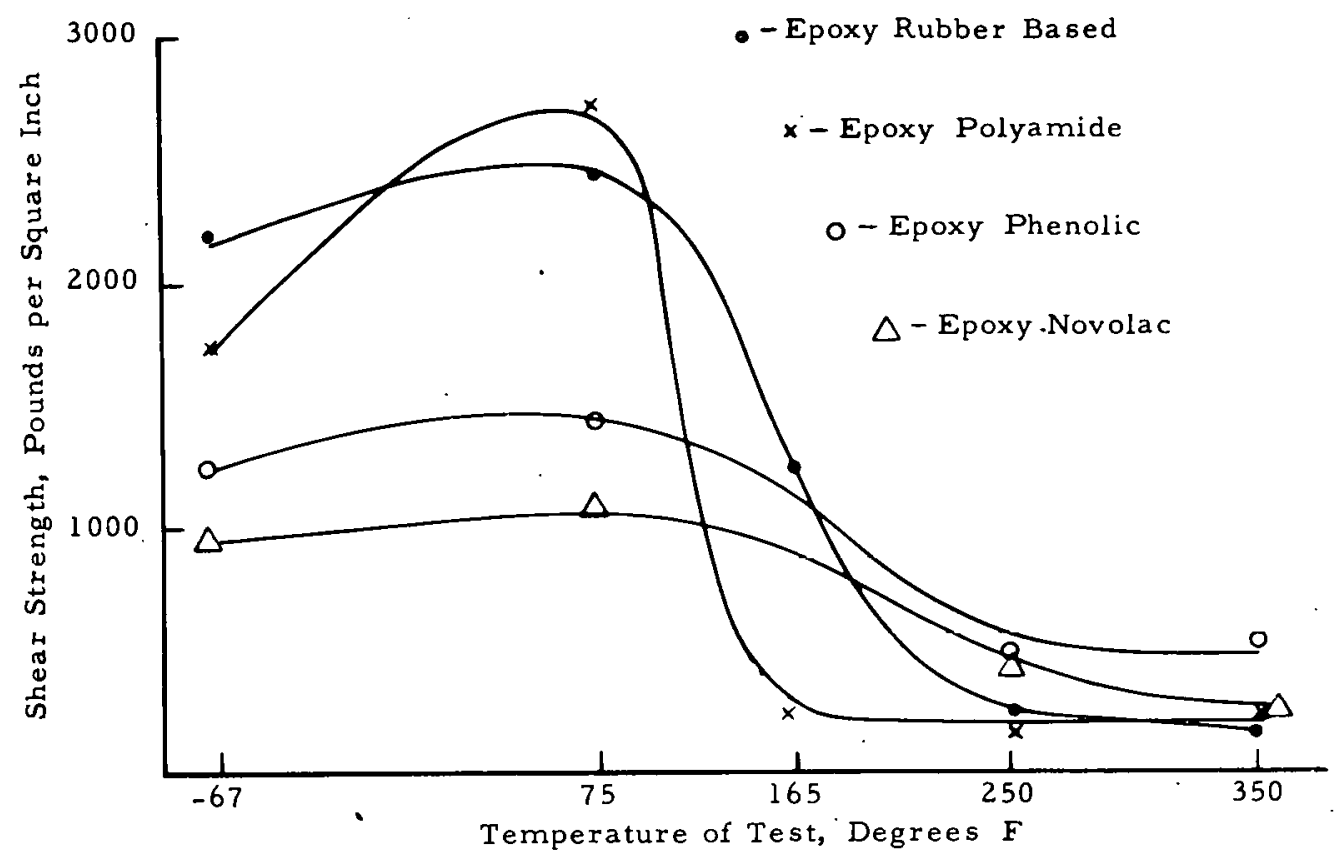

FIGURE 5.

Comparison of Shear Strength of HK31-H24 Magnesium Bonded with Four Epoxy Adhesives (Hot Chromic Acid Etch Surface Preparation). Cured Four Hours at 165 Degrees F.

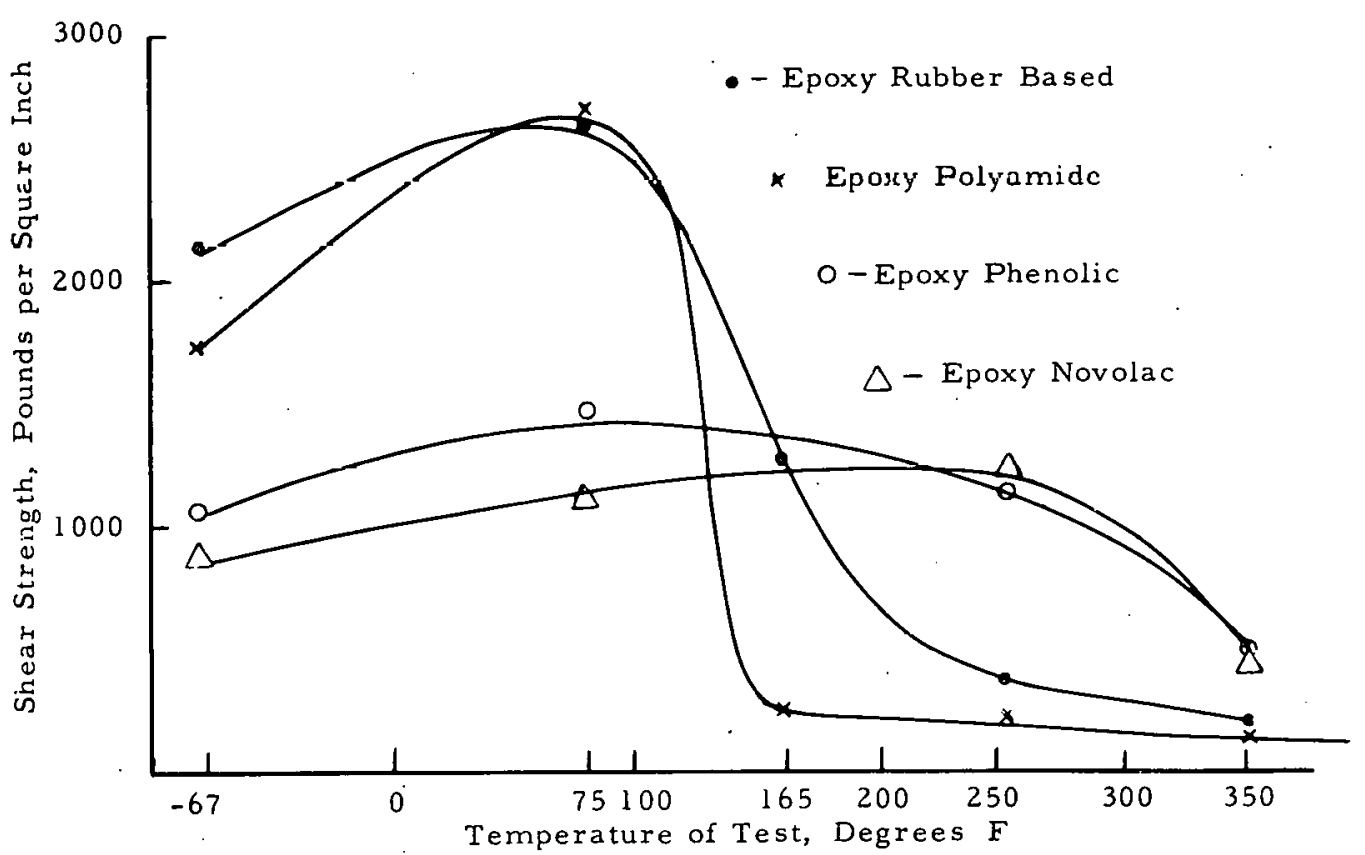




\section{FIGURE 6.}

Comparison of Shear Strength of LAl41-0 Magnesium Bonded with Four Epoxy Adhesives (Hot Chromic Acid Etch Surface Preparation). Cured Four Hours at 165 Degrees F.

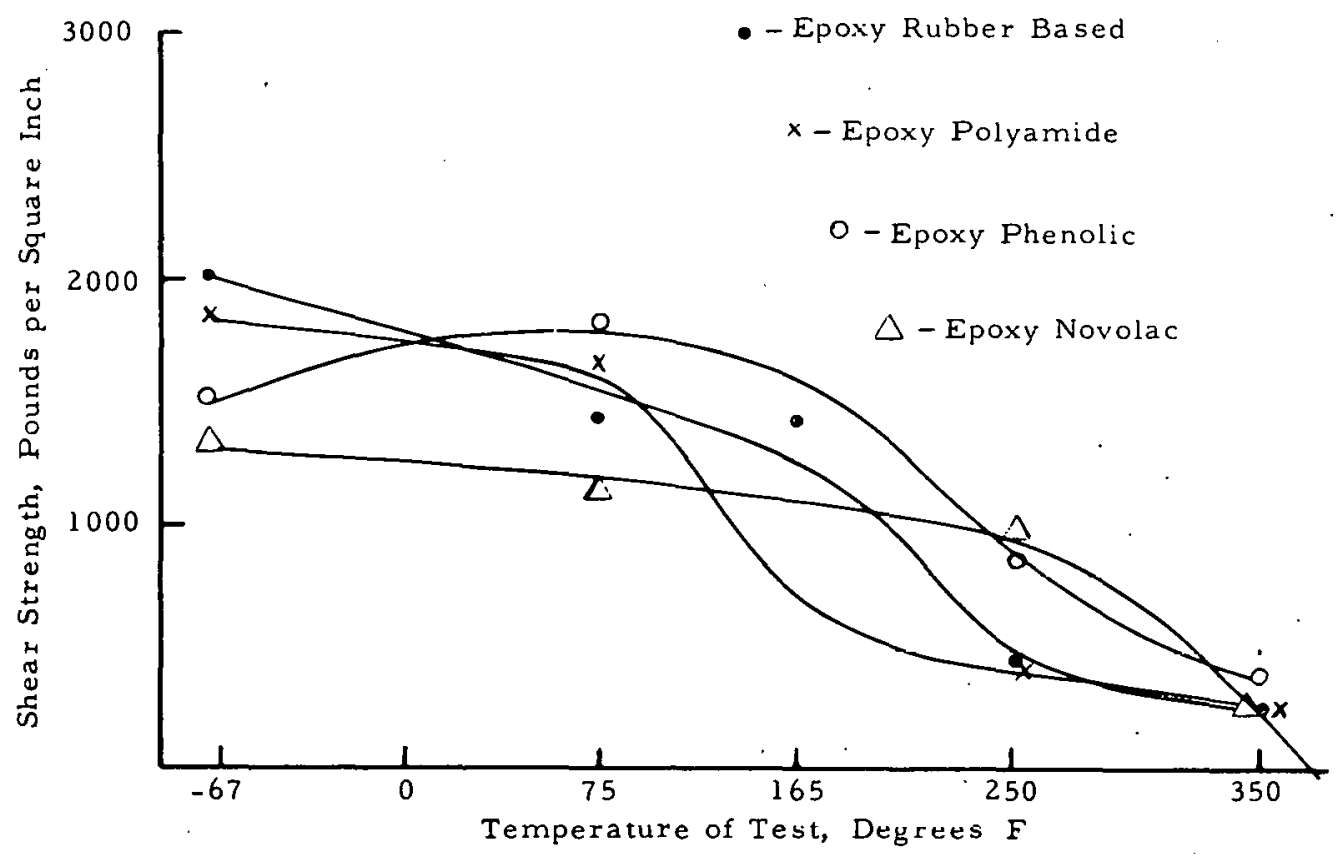

\section{TABLE IV}

Effects of Cure Temperature on Shear Strength of Bonded Magnesium Alloys

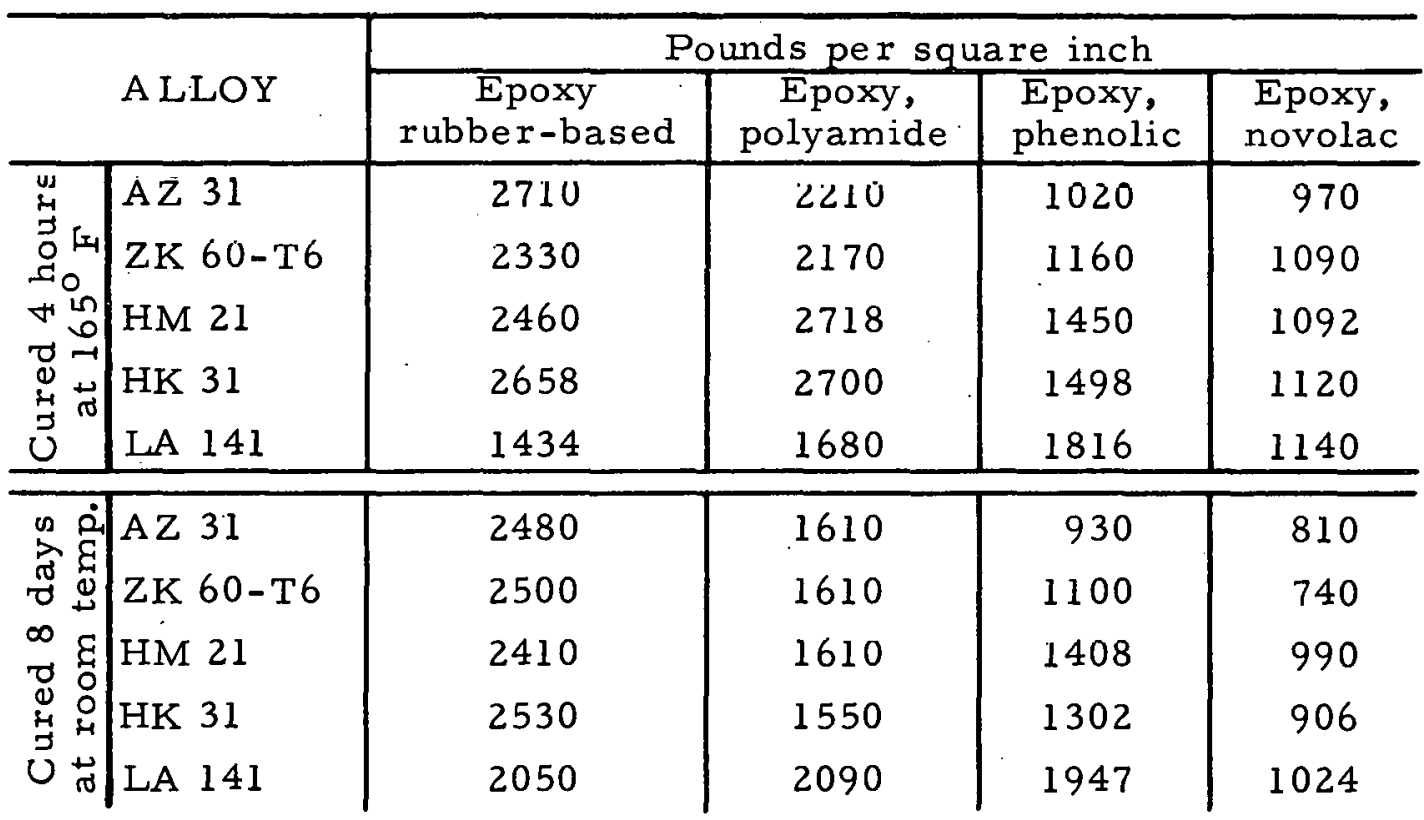


Thus, another factor to be considered is that the mechanism of the adhesive cure can also have an influence on the final bond strength obtained.

6. Time and Temperature Effects

The work with the chromic acid pickle solutions has shown, in some cases, that the temperature of the etching solution is important. Little shear strength difference was found with one of the magnesium alloys using one of the epoxy adhesives processed at room temperature through a chrome-nitrate pickle solution, whether for one minute or up to eleven minutes. With the same pickle solution at $150^{\circ} \mathrm{F}$, however, strength values differed, with greatest strengths obtained at seven to eleven minutes of immersion. However, removal of magnesium was excessive in the latter case.

\section{E. PROCESSING}

Whether parts are processed by immersion into the required solutions, or by successive flows of the required solutions and water rinses over the parts, the problems of contamination, solution depletion by drag-out, or chemical reaction must be considered.

\section{Contamination Effects}

In the case of the chromic acid (and chrome-nitrate) procedures that are preceded by an alkaline cleaning process, it might be of concern that the acid could be contaminated by the alkaline solution for one reason or another. Conversely, depending upon the process used, the acid could contaminate the caustic. The ability of caustic solutions to pick up carbon dioxide from the air might also be another source of contamination.

An indication of the se contamination effects was obtained by processing one of the alloys through the entire chromic acid procedure and bonding with one of the adhesives. Normally; the alkaline cleaner has a $\mathrm{pH}$ of aboint 12. 7. The chromic acid solution was added to the alkaline cleaner in various increments. When a $\mathrm{pH}$ of about 10.0 was obtained, the normally bright, clean surface of the magnesium changed to a white stain. At a pH of about 9.0 a black stain occurred, accompanied by a subsequent lowering of adhesive bond strength.

If carbon dioxide were picked up from the air in large enough quantities, one would find that at a $\mathrm{pH}$ of about 10.0 a large drop-off in shear strength could be expected. However, staining of the magnesium was not observed in this case.

Dilution of the chromic acid by the previous water rinses or by the alkaline solution would, of course, reduce the life of the etch solution. In the latter case, this would be expected to reduce the effectiveness of the chemical treatment. 


\section{Solution Controls}

The chromic acid surface preparation procedures require a $\mathrm{pH}$ control on the caustic and desirably on the acid solution as well. It would appear that a minimum level of $\mathrm{pH} 11.0$ would be in order for the alkaline solution. Dilution and contamination effects might be controlled by keeping a maximum level of $\mathrm{pH} 0.5-1.0$ for the chromic acid. However, a more pertinent control on the chromic acid solutions would be the analysis of the hexavalent and the trivalent chrome ion. As magnesium is processed through the acid, the hexavalent chrome ion is converted to the trivalent chrome ion. Determination of the hexavalent chrome ion can be made by titration, using a ferrous ammonium sulfate and potassium manganate procedure. Total chrome ion (hexa and trivalent) can be determined by means of an ammonium persulfate oxidation method.

In the case of the Ebonol procedure, it can be expected that the effectiveness of the blackening solution will be reduced as the magnesium is processed through the solution. A minimum inorganic oxidizing agent content of the solution is needed to be maintained. The method available for the assay analysis is based on the potassium iodide-sodium thiosulfate titration technique.

According to the Dow lite rature, analysis of the Dow solution should be made for the dichromate, the phosphoric acid, and the fluoride level. Procedures are given in the handbook for "Magnesium Finishing".

\section{Packaging}

Since magnesium has a high degree of reactivity, care must be exercised in selecting the material for packaging. Magnesium in contact with other metals provides a potential for corrosion. Oils are generally used for protection from contamination during storage or shipment. Kraft paper will cause corrosion, probably because of the salts used in this type of paper. Protection of magnesium that is inprocess might be obtained by packaging in essentially non-reactive materials, such as cotton linter paper, polyethylene, or urethanes. 


\section{APPENDIX I}

\section{PROCEDURES USED FOR PREPARING MAGNESIUM SURFACES FOR ADHESIVE BONDING}

\section{SOLVENT CLEANING}

1. Acetone was used.

II. CHROMIC ACID (Hot)

1. Solvent degrease.

2. Immerse for 10 minutes at $160-190^{\circ} \mathrm{F}$ in the following solution:
Sodium metasilicate
3. $0 \mathrm{oz} /$ gallon.
Tetrasodium pyrophosphate
1. $5 \mathrm{oz} / \mathrm{gallon}$
Sodium hydroxide
1. $5 \mathrm{oz} / \mathrm{gallọ}$
Detergent
$0.5 \mathrm{oz} /$ gallon
Water, demineralized
1 gallon

3. Rinse in demineralized water at room temperature.

4. Immerse for 10 minutes at $150-160^{\circ} \mathrm{F}$ in the following aqueous solution:

Chromium trioxide

20 percent by weight

5. Rinse in demineralized water at room temperature.

6. Air dry.

III. CHROMIC ACID (Room Temperature)

The procedure is the same as that for the Chromic Acid (Hot) method, para. II above, except to substitute the following for Step 4:

Immerse in the following solution for two minutes at room temperature:
Chromium trioxide
$24 \mathrm{oz} / \mathrm{gallon}$
Water, demineralized
1 gallon 
IV. CAUSTIC

The procedure is the same as that for the Chromic Acid (Room Temperature) method, para. III above, but followed by immersion in the following solution for $1-3$ minutes at $180^{\circ} \mathrm{F}$ :

$$
\begin{array}{ll}
\text { Sodium hydroxide } & 12-16 \mathrm{oz} / \text { gallon } \\
\text { Water, demineralized } & 1 \text { gallon }
\end{array}
$$

The immersion is followed by a room temperature demineralized water rinse and air dry.

V. DOW 17

The procedures recommended in the "Magnesium Finishing" handbook, published by the Dow Chemical Company, were followed in anodizing the magnesium alloys. The following formulas for A. C. voltage were used at both 165 and $175^{\circ} \mathrm{F}$.

Anodizing Conditions Magnesium

\begin{tabular}{l|c|c|c|c|c}
\hline Alloy & AZ 31 & ZK 60-T6 & HM 21 & HK 31 & LA 141 \\
\hline AC Voltage & 70 & 50 & 60 & 70 & 45
\end{tabular}

It appears that more work than that reported here needs to be done to determine the optimum conditions for the Dow 17 coating application on LA 141.

VI. EBONOL "C"

1. Solvent degrease.

2. Immerse panels for $13-15$ minutes at $200-215^{\circ} \mathrm{F}$ in the following solution:

$$
\begin{array}{ll}
\text { Ebonol "C"Special* } & 24 \mathrm{oz} / \text { gallon } \\
\text { Water, demineralized } & 1 \text { gallon } .
\end{array}
$$

3. Rinse in flowing, demineralized, room-temperature water for one minute.

4. Immerse and gently agitate in warm $\left(120-140^{\circ} \mathrm{F}\right)$ demineralized water for one minute.

5. Oven-dry at $120-140^{\circ} \mathrm{F}$ for one hour.

*Ebonol "C" Special is a product of Enthone, Incorporated, New Haven, Connecticut. 


\section{APPENDIX II}

\section{REFERENCES}

1. Meyer, W. R., "Process for Blackening Copper or Copper Alloy Surfaces", U. S. Patent 2, 364, 993, December 12, 1944.

2. Meyer, W. R., "Composition for Blackening Copper and Copper Alloy Surfaces", U. S. Patent 2, 460, 896, February 8, 1949.

3. Meyer, W. R., "Process and Composition for Coloring Copper and Copper Alloy Surfaces", U. S. Patent 2, 460, 898, February 8, 1949.

4. METALS HANDBOOK, Volume I, American Society for Metals, March, 1964.

5. Specification BP-S-125B, Rev. November 15, 1963, Brook and Perkins Company, Detroit, Michigan.

6. "Magnesium Finishing", The Dow Metal Products Company, Division of The Dow Chemical Company, Midland, Michigan, 1958. 